\title{
Control of citrus mealybug Planococcus citri (Risso) on three grapevines varieties and its effect on fruits quality
}

\author{
Fahmy, A.M ${ }^{1}$, E.H. Salem ${ }^{2}$ and R.O.H. Allam ${ }^{3 *}$ \\ ${ }^{1}$ Plant Protection Department, Faculty of Agriculture and Natural Resources, Aswan University, Egypt \\ ${ }^{2}$ Horticulture Pomology Department, Faculty of Agriculture and Natural Resources, Aswan University, Egypt \\ ${ }^{3}$ Plant Protection Department, Faculty of Agriculture, South Valley University, Egypt.
}

\begin{abstract}
Grape mealybug consider the most universally important vineyard insect pest. Insecticides are the main strategy to grapevine insect control. The result showed that the recommended rate of Imidacloprid is succeeded in controlling of mealybug since its initial reduced of the infestation were 89.26, 84.21and $85.71 \%$ for first season and 82.71, 82.94 and $83.56 \%$ for second season for Flame seedless, Early sweet seedless and Sugraone seedless, respectively. Meanwhile, the total mean of reduction after 3,7, 14 and 30 days were 95.79, 64.83 and $72.82 \%$ for first season and 85.20, 66.33 and $69.84 \%$ for second season on Flame seedless, Early sweet seedless and Sugraone seedless, respectively. On the other hand, the total mean of reduction after 3,7, 14 and 30 days were 72.56, 80.40 and $82.50 \%$ for first season and 68.88, 76.13 and $75.56 \%$ for second season on Flame seedless, Early sweet seedless and Sugraone seedless, respectively. In addition, all of them are above $70 \%$ reduction. From these results, it should be suggested using some effective alternatives such as Palmito compound in controlling mealy bug incompatible program with chemical insecticides instead of conventional individuals' insecticides. The grapevine variety, Early sweet seedless showed the significant superiority in the quality traits. Under conditions of this investigation, the grapevine variety, Early sweet seedless was recorder the highest values for yield per vine, TSS and total sugar\% in both seasons.
\end{abstract}

Keywords: Insecticide grapevine; Citrus mealybug; Variety.

\section{Introduction}

Grapevine, Vitis vinifera L. is traditionally cultivated as fruit crop all over the world, which it used as wines or food tables. In Egypt, the grape as fruit summer is very essential to most Egyptian people as food table and exportation to some European countries. The quantity and quality properties of fruit are very important for direct feeding or integrated industries of grape food. One of the most important factors that affected grape productions is insect pests. Planococcus citri, Risso (Hemiptera: Pseudococcidae), known as citrus mealybug, is a most crucial polyphagous

\footnotetext{
*Corresponding author: R.O.H. Allam

Email: refat.edu.eg@gmail.com

Received: March 27, 2021; Accepted: June 8, 2021;

Published online: June 21, 2021.

(C) Published by South Valley University.

This is an open access article licensed under cc)(이
}

pest on many plants around the world including the grapevine (Özgökçe et al., 2018). It is a highly polyphagous and most crucial pest around the world. In addition, it is a common pest on citrus, grapevine, ornamental plants, cocoa, bananas, tobacco, coffee, passionfruits, pineapples, figs, taro, date palms, pomegranates, potatoes, and greenhouse plants (Williams and Watson 1988). Planococcus citri and P. ficus is morphologically very similar, and their separation is very difficult (Williams and Granar de Willink, 1992). It was reported that $\mathrm{Pl}$. citri is the most abundant in vineyards (Morandi Filho et al., 2008) than P. ficus (Foldi and Kozar, 2006). The biology of $P l$. citri is little known, although it is native to Eurasia, and has recently been regarded as an 
economically important pest (Daane et al., 2012).

The importance of the grape mealybug, as a pest of wine grapes, Vitis vinifera $\mathrm{L}$. (Vitaceae), has increased because of recent reports that it can transmit at least one of the viruses associated with grapevine leafroll disease. The grape mealybug is a pest of various tree fruits (including pears, apples, and apricots) as well as grapes (Doutt \& Hagen, 1950; Madsen \& McNelly, 1960; Grasswitz \& Burts, 1995). The most important vineyard mealybugs belong to the subfamily Pseudococcinae (Hardy, et al., 2008). Although, there are numerous mealybug species are found in vineyards. Mealybugs are phloem feeders that use long, slender mouthparts to suck out plant fluids (McKenzie, 1967). Most of the vineyard mealybugs can feed on the vine's root, trunk, canes, leaves, or berry clusters. There are, however, differences in the amount of damage caused by each species. This is often related to those factors that determine population size (e.g., number of annual generations and female fecundity), preferred feeding locations, and temperature tolerances. As the mealybugs feed, they eliminate carbohydrate-rich honeydew, which can accumulate on the leaves and in the grape clusters, especially in late summer and early fall (Charles, 1982). The mealybug honeydew away from its location, but it still accumulates on the vine. It has long been noted that honeydew serves as a substrate for the development of sooty mold fungi that can result in further vine damage. For table grape growers, any live or dead mealybugs and the honeydew or sooty molds will cause cosmetic damage to the grape cluster and reduce its marketability (Daane, et al., 2011).

Newer materials, with more novel modes of action, have also gained in popularity,

including neonicotinoids, bio pesticides, (Daane et al., 2006; SunithaS et al., 2009; Lo and Walker, 2010). A major difference between the older and newer materials is the importance of coverage, a portion of the mealybug population is often under the bark, and for some species, on the vine roots. Many of the older foliar sprays did not effectively contact and kill mealybugs in these more protected locations. Some of the more novel materials have systemic properties, either applied through the irrigation system or as a foliar spray. For organic or sustainable farming programs, bio pesticides have been used. The few studies of these products have provided mixed results (Srinivas, et al., 2007). Applications with systemic insecticides near bloom are often used as the insecticide moves quickly in the vines to the leaves. After bloom, foliar materials are applied beneath the leaf canopy and aimed towards the grape clusters and interior canes.

Therefore, this study was aimed to the screening of the selected insecticides represented from different groups for citrus mealybug under open field conditions, efficiency of the selected insecticides using manufactures labels rate on the mealybug populations obtained from grape varieties was evaluated.

\section{Materials and methods}

\subsection{Tested insecticides}

The tested insecticides were:

1- Dursban 75 WG $250 \mathrm{~cm}$. / $100 \mathrm{~L}$ water (Chlorpyrifos).

2- Pestador $25 \%$ WP, 150 gm. / $100 \mathrm{~L}$ water (Imidacloprid).

3- Palmito compound, (Fe 1.5\%, Zn 1.5\%, Mn 1.5\%) $200 \mathrm{~cm} . / 100 \mathrm{~L}$ water

\subsection{Field experiment}


The present experiment was conducted during two successive seasons 2018/2019 and 2019/2020. Seven years old, Flame seedless, Sugraone seedless and Early sweet seedless grafted on freedom root stock grown in private vineyard (Vitis vinifera L.), located at, Luxor Governorate, Egypt. Vines were planted in sandy soil at $2 \mathrm{~m}$ between vines and $3 \mathrm{~m}$ between rows under drip irrigation system, $0.5 \mathrm{~m}$ distance between drippers. The soil texture was sand 85 , silt 9.5, clay $4.5, \mathrm{pH} 7.5$ and EC $1.9 \mathrm{dSm}^{-1}$. The main goal of the trial to evaluate influence of some insecticides on the infected vines with mealybug $P$. citri.

The experimental design was a split plot with three replications each contained 12 plots. Each replicate was a plot of $30 \mathrm{~m}^{2}(5$ vines grown $(2 * 3 \mathrm{~m})$. Insecticides (Factor A) were distributed in the main plot and table grapes varieties (Factor B) as a split plot. Foliar treatments were applied once at 15 of March and during the two successive seasons of 2018/2019 and 2019/2020.

The insecticides were sprayed using knapsack sprayer with one nozzle, as a foliar treatment, at a total volume of 200 liters per feddan. The control plots were sprayed with water. In addition, care was taken to avoid any drift among the treated plots.

The samples representing upper, middle, and lower leaves of the chosen trees were randomly picked and preserved in paper bags. All samples were transferred to the laboratory for an inspection, by a binocular microscope. Inspection of infestation was carried out just before spraying and 3,7,14 and 30 days after spraying. However, the infestation by this insect was determined by finding out number of different insect's phases on injured vines per plot. This pest identifies by specialists in the Research Department of Scale Insects and mealybugs, Plant Protection Research Institute, Agricultural Research Center. in Egypt.

Reduction percentages of infestation were estimated by (Henderson and Tilton, 1955) formula as follow: -

Reduction \% $=[1-(\mathrm{Ta} / \mathrm{Tb} \times \mathrm{Cb} / \mathrm{Ca})] \times 100$ Where: -

$\mathrm{Ta}=$ number of insects in treatments after application.

$\mathrm{Tb}=$ number of insects in treatments before application.

$\mathrm{Ca}=$ number of insects in check after application in treatment.

$\mathrm{Cb}=$ number of insects in check before application in treatment.

\subsection{Yield and Fruit Quality}

Yield/vine was calculated in $\mathrm{kg}$ was expressed as average weight of cluster $(\mathrm{kg}) \mathrm{x}$ number of cluster/vines using the digital scale. Berry diameter was calculated per mm using hand sizer all measurements were in the field at harvest time.

Berry chemical quality characteristics: Sample of 12 clusters per treatment, each replicate consists of four clusters were harvested to measure the physical and chemical characteristics of clusters.

1- Total soluble solids content (TSS) \% was measured as a percent in juice of fresh berries, the hand refractometer was used in that respect.

2- Reducing sugar according to A.O.A.C (1985).

3- Titratable acidity (\%) was measured as $\mathrm{mg}$ of tartaric acid using titration of 5 ml clear juice against $(0.1 \mathrm{~N}) \mathrm{NaOH}$ after the addition of a little drops of phenol pthalene indicator. A.O.A.C (1985). 
4- Berry diameter ( $\mathrm{mm})$ : The average diameter of berries was measured by using a hand sizer caliper.

\subsection{Statistical analysis}

Statistical analysis of data was carried out by using a computer software package " MSTATC ". L.S.D test was used to differentiate between means.

\section{Results and discussion}

\subsection{Field application of insecticides and their alternatives}

The field experiments were carried out to evaluate the reduction of three insecticides namely, Palmito, chlorpyrifos and Imidacloprid on three different variety namely Flame seedless, Early sweet seedless and Sugraone seedless during 2018/2019 and 2019/2020 seasons.

Data in table (1) showed that reduction percent of infestation by mealybug due to the application of tested insecticides and their alternatives indicated that Imidacloprid was the most effective insecticides in reducing the infestation. It exhibited that the initial reduction was $89.26,85.71$ and $84.21 \%$ on Flame seedless, Sugraone seedless and Early sweet seedless respectively during 2018/2019 season.

Table 1. Effect of Imidacloprid, Chlorpyrifos and Palmito on citrus mealybug infesting grapevines during 2018/2019 for first season.

\begin{tabular}{|c|c|c|c|c|c|c|c|}
\hline \multirow{2}{*}{ Insecticides } & \multirow{2}{*}{ Varieties } & \multirow{2}{*}{ Before } & \multicolumn{4}{|c|}{$\%$ Reduction } & \multirow{2}{*}{ mean } \\
\hline & & & 3 & 7 & 14 & 30 & \\
\hline \multirow{3}{*}{ Palmito } & Flame seedless & 10.00 & 72.09 & 54.06 & 85.12 & 78.98 & 72.56 \\
\hline & Early sweet seedless & 10.67 & 70.06 & 62.70 & 94.43 & 94.43 & 80.40 \\
\hline & Sugraone seedless & 8.67 & 72.12 & 65.52 & 96.18 & 96.18 & 82.50 \\
\hline \multirow{3}{*}{ Chlorpyrifos } & Flame seedless & 9.00 & 76.33 & 59.19 & 61.13 & 61.61 & 64.56 \\
\hline & Early sweet seedless & 8.00 & 82.03 & 76.44 & 87.82 & 80.04 & 81.58 \\
\hline & Sugraone seedless & 6.33 & 78.28 & 97.22 & 91.27 & 97.22 & 91.00 \\
\hline \multirow{3}{*}{ Imidacloprid } & Flame seedless & 7.33 & 89.26 & 93.89 & 100.00 & 100.00 & 95.79 \\
\hline & Early sweet seedless & 16.00 & 84.21 & 62.23 & 67.43 & 45.45 & 64.83 \\
\hline & Sugraone seedless & 12.33 & 85.71 & 62.52 & 76.32 & 66.86 & 72.85 \\
\hline
\end{tabular}

According to the recommendation of the Egyptian ministry of agriculture for using insecticides and their alternatives in controlling pests, effective materials should give initial effect not less than $70 \%$ reduction and residual effect not less than $40 \%$ reduction (Anonymous, 2001). The present data stated that tested insecticides could be arranged in descending order according to their potency as follows: Imidacloprid > Chlorpyrifos > Palmito.

Based on this recommendation, the result in Tables 1 and 2 showed that the recommended rate of Imidacloprid is succeeded in controlling of mealybug since its initial reduced of the infestation were $89.26,85.71$ and $84.21 \%$ for first season and $83.56,82.94$ and $82.71 \%$ for second season, respectively. Meanwhile, the total mean of reduction after 3,7, 14 and 30 days were 95.79, 72.82 and $64.83 \%$ for first season and 85.20, 69.84 and $66.33 \%$ for second season on Flame seedless, Sugraone seedless and Early sweet seedless, respectively. While the initial reduction of Chlorpyrifos were $82.03,78.28$ and $76.33 \%$ on Early sweet seedless, Sugraone seedless and Flame seedless, respectively at first season. While the initial reduction of Chlorpyrifos were 78.41, 77.72 and $66.03 \%$ on Early sweet seedless, Flame seedless and Sugraone seedless, respectively at second season. These results in agree with Kent $e t$ 
al. (2020) stated that there was little difference in infestation levels between plots treated with imidacloprid $(50.5 \pm 0.1 \%)$ and buprofezin $(47.6 \pm 0.1 \%)$ and for that reason, data were combined.

While the initial reduction of Palmito were $72.12,72.09$ and $70.06 \%$ on Sugraone seedless, Flame seedless and Early sweet seedless, respectively at first season. While the initial reduction of Palmito were 71.05, 71.00 and $70.90 \%$ on Early sweet seedless, Flame seedless and Sugraone seedless, respectively at second season. Meanwhile, the total mean of reduction after $3,7,14$ and 30 days were $72.56,80.40$ and $82.50 \%$ for first season and $68.88,76.13$ and $75.56 \%$ for second season on Flame seedless, Early sweet seedless and Sugraone seedless, respectively. In addition, all of them are above $70 \%$ reduction. From these results, it should be suggested using some effective alternatives such as Palmito in controlling mealybug incompatible program with chemical insecticides instead of conventional individuals' insecticides.

These results agreed with those of (Chowański, et al., 2014) stated that, insecticides extracted from plants have less negative environmental effects and create comparatively low risk of insecticide resistance than synthetic insecticides; therefore, they can be proposed as a safe tool for management of pests.

Several problems have resulted from the intensive use of conventional pesticides for pest control such as insect resistance; outbreaks of pest population; destruction of non-pest species; environmental pollution and human health hazards. Palmito compound could be considered promising alternatives to conventional insecticides for use against the citrus mealybug. These findings agreed with those reported by many investigators (Maurya and Malik, 2016).

Table 2. Effect of Imidacloprid, Chlorpyrifos and Palmito on citrus mealybug infesting grapevines during 2019/2020 for second

\begin{tabular}{|c|c|c|c|c|c|c|c|}
\hline \multirow[t]{2}{*}{ Insecticides } & \multirow[t]{2}{*}{ Varieties } & \multirow[t]{2}{*}{ Before } & \multicolumn{4}{|c|}{$\%$ Reduction } & \multirow[t]{2}{*}{ mean } \\
\hline & & & 3 & 7 & 14 & 30 & \\
\hline \multirow[t]{3}{*}{ Palmito } & Flame seedless & 11.33 & 71.00 & 54.70 & 81.15 & 68.65 & 68.88 \\
\hline & Early sweet seedless & 11.00 & 71.05 & 58.05 & 89.41 & 86.00 & 76.13 \\
\hline & Sugraone seedless & 9.00 & 70.90 & 64.81 & 82.75 & 83.80 & 75.56 \\
\hline \multirow[t]{3}{*}{ Chlorpyrifos } & Flame seedless & 9.67 & 77.72 & 64.19 & 59.02 & 54.86 & 63.95 \\
\hline & Early sweet seedless & 9.33 & 78.41 & 74.39 & 79.37 & 74.00 & 76.54 \\
\hline & Superior seedless & 7.00 & 66.03 & 81.55 & 77.51 & 70.61 & 73.92 \\
\hline \multirow[t]{3}{*}{ Imidacloprid } & Flame seedless & 9.00 & 82.71 & 84.22 & 89.83 & 84.05 & 85.20 \\
\hline & Early sweet seedless & 16.33 & 82.94 & 69.01 & 62.94 & 50.41 & 66.33 \\
\hline & Sugraone seedless & 13.33 & 83.56 & 62.87 & 70.52 & 62.41 & 69.84 \\
\hline
\end{tabular}

The initial deposit of Imidacloprid was above $80 \%$ which indicate that the conventional insecticides exhibited outstanding potency in reducing infestation by citrus mealybug as compared with alternatives insecticides. However, this is not enough to recommend using these insecticides widely in controlling this pest species. It is better to suggest using alternatives of insecticides in controlling mealybug incompatible program with other controlling agents instead of the conventional insecticides.

Data are presented in Tables (1 and 2) indicated that all the used insecticides had affected the insect population. The insecticides could be arranged according to their potency 
as follow: Imidacloprid > Chlorpyrifos > Palmito.

The most effective insecticide was Imidacloprid while Palmito compound was the least effective one. On the other hand, Chlorpyrifos located in between. Data clearly show that there is a wide range in the response of the insects to the action of the three tested compounds. It is obvious that percent reduction of infestation depended on the type of used compounds and grape varieties.

The present study recommends that Imidacloprid insecticide was better than chlorpyrifos in control of citrus mealybug. Palmito compound give good control of citrus mealybug and should use as alternative candidate, so it should be considered in integrated pest management (IPM) programs of control programme of citrus mealybug.

\subsection{Yield and Fruit Quality}

\subsection{1. yield /vine (kg)}

Data in Table (3) showed that the yield per vine $(\mathrm{kg})$ was significantly affected by spraying with different insecticides in the $1^{\text {st }}$ and $2^{\text {nd }}$ seasons. Imidacloprid recorded highest yield per vine (7.69 and 7.36) in the $1^{\text {st }}$ season and $2^{\text {nd }}$ season, respectively compared with untreated vines (4.98 and 4.64). Meanwhile, Palmito compound was recorded the least yield per vine (7.22 and 6.88) in the $1^{\text {st }}$ and $2^{\text {nd }}$ seasons, respectively. Decreasing yield per vine due to mealybugs feed on plant sap they often excrete a sugary, sticky liquid called honeydew. While the honeydew usually does not cause severe damage by itself, it frequently attracts ants and other insect pests, can cause mold which leaves grapes cosmetically damaged and can prevent a good drying of the grapes if producing raisins. The honeydew of mealybugs can also encourage the development of bacteria or fungus, such as black sooty mold which prevents sunlight from penetrating the leaves and cane inhibit plant growth.

Table 3. Effect of grape varieties and different application insecticides on the yield per vine $(\mathrm{kg})$ at harvest in the $1^{\text {st }}$ and $2^{\text {nd }}$ seasons, 2018/2019 and 2019/2020.

\begin{tabular}{|c|c|c|c|c|c|c|c|c|}
\hline \multirow[t]{2}{*}{ Insecticides } & \multicolumn{3}{|c|}{ Yield per vine (kg) 2018/2019 } & \multirow[t]{2}{*}{ Mean } & \multicolumn{3}{|c|}{ Yield per vine (kg) 2019/2020 } & \multirow[t]{2}{*}{ Mean } \\
\hline & $\begin{array}{c}\text { Flame } \\
\text { seedless }\end{array}$ & $\begin{array}{c}\text { Early } \\
\text { sweet } \\
\text { seedless }\end{array}$ & $\begin{array}{c}\text { Sugraone } \\
\text { seedless }\end{array}$ & & $\begin{array}{c}\text { Flame } \\
\text { seedless }\end{array}$ & $\begin{array}{c}\text { Early } \\
\text { sweet } \\
\text { seedless }\end{array}$ & $\begin{array}{l}\text { Sugraone } \\
\text { seedless }\end{array}$ & \\
\hline Palmito & 6.73 & 7.47 & 7.45 & 7.22 & 6.40 & 7.13 & 7.12 & 6.88 \\
\hline Chlorpyrifos & 6.90 & 8.03 & 7.63 & 7.52 & 6.57 & 7.70 & 7.30 & 7.19 \\
\hline Imidacloprid & 6.87 & 8.20 & 8.00 & 7.69 & 6.53 & 7.87 & 7.67 & 7.36 \\
\hline Nun insecticides & 4.33 & 5.53 & 5.07 & 4.98 & 4.00 & 4.73 & 5.20 & 4.64 \\
\hline Mean & 6.21 & 7.31 & 7.04 & & 5.88 & 6.86 & 6.82 & \\
\hline \multicolumn{9}{|l|}{ L.S.D. at 0.05} \\
\hline Insecticides (A) & \multicolumn{3}{|c|}{0.32} & \multicolumn{5}{|c|}{0.57} \\
\hline \multicolumn{9}{|l|}{ Grape varieties (B) } \\
\hline \multirow[t]{2}{*}{$\mathrm{A} \times \mathrm{B}$} & \multicolumn{3}{|c|}{0.58} & \multicolumn{5}{|c|}{0.42} \\
\hline & \multicolumn{3}{|c|}{ NS } & \multicolumn{5}{|c|}{0.84} \\
\hline
\end{tabular}

Data presented in Table (3) suggested that, the grape varieties differed significantly in yield per vine $(\mathrm{kg})$. The yield (7.31 and 6.86) was observed in Early sweet seedless during the first and second seasons, respectively. Whereas the lowest yield per vine $(6.21$ and
$5.88 \mathrm{~kg}$ ) was observed in Flame seedless in both seasons, respectively. These results agreed with Bashandy et al. (2020) found that, there were significant differences between the studded cultivars in physical quality parameters. The interaction between grape 
varieties and different insecticides showed the significant differences in second season.

Table 4. Effect of grape varieties and different application insecticides on the Total soluble solids (TSS) at harvest in the $1^{\text {st }}$ and $2^{\text {nd }}$ seasons, 2018/2019 and 2019/2020.

\begin{tabular}{|c|c|c|c|c|c|c|c|c|}
\hline \multirow[t]{2}{*}{ Insecticides } & \multicolumn{3}{|c|}{ TSS (2018/2019) } & \multirow[t]{2}{*}{ Mean } & \multicolumn{3}{|c|}{ TSS (2019/2020) } & \multirow[t]{2}{*}{ Mean } \\
\hline & $\begin{array}{c}\text { Flame } \\
\text { seedless }\end{array}$ & $\begin{array}{c}\text { Early } \\
\text { sweet } \\
\text { seedless }\end{array}$ & $\begin{array}{c}\text { Sugraonese } \\
\text { edless }\end{array}$ & & $\begin{array}{c}\text { Flame } \\
\text { seedless }\end{array}$ & $\begin{array}{c}\text { Early } \\
\text { sweet } \\
\text { seedless }\end{array}$ & $\begin{array}{c}\text { Sugraonese } \\
\text { edless }\end{array}$ & \\
\hline Palmito & 14.13 & 14.80 & 14.13 & 14.36 & 13.80 & 14.47 & 13.80 & 14.02 \\
\hline Chlorpyrifos & 14.80 & 14.93 & 14.47 & 14.73 & 14.47 & 14.60 & 14.13 & 14.40 \\
\hline Imidacloprid & 14.93 & 14.90 & 14.73 & 14.86 & 14.57 & 14.60 & 14.40 & 14.52 \\
\hline Nun insecticides & 12.40 & 13.33 & 12.53 & 12.76 & 12.07 & 13.00 & 12.20 & 12.42 \\
\hline Mean & 14.07 & 14.49 & 13.97 & & 13.73 & 14.17 & 13.63 & \\
\hline \multicolumn{9}{|l|}{ L.S.D. at 0.05} \\
\hline Insecticides (A) & \multicolumn{3}{|c|}{0.52} & \multicolumn{5}{|c|}{0.55} \\
\hline Grape varieties (B) & & & & \multicolumn{5}{|c|}{0.38} \\
\hline \multirow[t]{2}{*}{$\mathrm{A} \times \mathrm{B}$} & \multicolumn{3}{|c|}{0.47} & & & & & \\
\hline & \multicolumn{3}{|c|}{ NS } & \multicolumn{5}{|c|}{ NS } \\
\hline
\end{tabular}

Table 5. Effect of grape varieties and different application insecticides on the Reducing sugars $\%$ at harvest in the $1^{\text {st }}$ and $2^{\text {nd }}$ seasons, 2018/2019 and 2019/2020.

\begin{tabular}{|c|c|c|c|c|c|c|c|c|}
\hline \multirow[t]{2}{*}{ Insecticides } & \multicolumn{3}{|c|}{ Reducing sugars \% (2018/2019) } & \multirow[t]{2}{*}{ Mean } & \multicolumn{3}{|c|}{ Reducing sugars \% (2019/2020) } & \multirow[t]{2}{*}{ Mean } \\
\hline & $\begin{array}{c}\text { Flame } \\
\text { seedless }\end{array}$ & $\begin{array}{c}\text { Early } \\
\text { sweet } \\
\text { seedless }\end{array}$ & $\begin{array}{l}\text { Sugraone } \\
\text { seedless }\end{array}$ & & $\begin{array}{c}\text { Flame } \\
\text { seedless }\end{array}$ & $\begin{array}{c}\text { Early } \\
\text { sweet } \\
\text { seedless }\end{array}$ & $\begin{array}{l}\text { Sugraone } \\
\text { seedless }\end{array}$ & \\
\hline Palmito & 11.30 & 11.47 & 11.47 & 11.41 & 11.45 & 11.68 & 11.58 & 11.57 \\
\hline Imidacloprid & 11.48 & 11.73 & 11.61 & 11.61 & 11.75 & 11.87 & 11.70 & 11.77 \\
\hline Nun insecticides & 9.38 & 9.73 & 9.54 & 9.55 & 9.64 & 9.92 & 9.92 & 9.82 \\
\hline Mean & 10.90 & 11.15 & 11.02 & & 11.10 & 11.31 & 11.19 & \\
\hline \multicolumn{9}{|l|}{ L.S.D. at 0.05} \\
\hline Insecticides (A) & & 0.22 & & & & 0.19 & & \\
\hline \multirow{2}{*}{$\begin{array}{l}\text { Grape varieties (B) } \\
\mathrm{A} \times \mathrm{B}\end{array}$} & & 0.49 & & & & 0.23 & & \\
\hline & & NS & & & & NS & & \\
\hline
\end{tabular}

\subsubsection{Total soluble solids (TSS)}

Data presented in Table (4) indicated the TSS was significantly affected by spraying with different insecticides in the $1^{\text {st }}$ and $2^{\text {nd }}$ seasons. Imidacloprid recorded highest TSS (14.86 and 14.52) in the $1^{\text {st }}$ season and $2^{\text {nd }}$ season respectively, compared with untreated vines (12.76 and 12.42). Meanwhile, Palmito compound was recorded the least TSS (14.36 and 14.02) in the $1^{\text {st }}$ and $2^{\text {nd }}$ seasons, respectively.

Results given in Table (4) show that the grape varieties differed significantly in TSS. The highest TSS (14.49 and 14.17) was observed in Early sweet seedless during the first and second seasons, respectively. Whereas the lowest TSS (13.97 and 13.63) was observed in Sugraone seedless in both seasons, respectively. The obtained results matched with El-Salhy et al. (2019) stated that, TSS and reducing sugar values in Early sweet cultivar were 14.9 and 12.11, respectively, these results are close to our results.

The interaction between grape varieties and different insecticides showed the insignificant differences in both seasons. 


\subsubsection{Reducing sugars $\%$}

Data in Table (5) showed that the Reducing sugars $\%$ was significantly affected by spraying with different insecticides in the $1^{\text {st }}$ and $2^{\text {nd }}$ seasons. Imidacloprid recorded highest Reducing sugars \% (11.61 and 11.77) in the $1^{\text {st }}$ season and $2^{\text {nd }}$ season, respectively, compared with untreated vines $(9.55$ and 9.82). Meanwhile, Palmito compound was recorded the lowest reducing sugars \% (11.41and $11.57)$ in the $1^{\text {st }}$ and $2^{\text {nd }}$ seasons, respectively.
Data arranged in Table (5) showed that the grape varieties differed significantly in reducing sugars $\%$. The highest reducing sugars $\%$ (11.15 and 11.31) was observed in Early sweet seedless during the first and second seasons, respectively. Whereas the lowest Reducing sugars \% (10.90 and 11.10) was observed in Flame seedless in both seasons, respectively. The obtained results matched with El-Salhy et al. (2019) reported that TSS and reducing sugar values in Early sweet cultivar were 14.9 and 12.11 , respectively, these results are close to our results. The interaction between grape varieties and different insecticides showed the insignificant differences in both seasons.

Table 6. Effect of grape varieties and different insecticides on the Titratable acidity $\%$ at harvest in the $1^{\text {st }}$ and $2^{\text {nd }}$ seasons, $2018 / 2019$ and 2019/2020.

\begin{tabular}{|c|c|c|c|c|c|c|c|c|}
\hline \multirow[t]{2}{*}{ Insecticides } & \multicolumn{3}{|c|}{ Titratable acidity \% (2018/2019) } & \multirow[t]{2}{*}{ Mean } & \multicolumn{3}{|c|}{ Titratable acidity \% (2019/2020) } & \multirow[t]{2}{*}{ mean } \\
\hline & $\begin{array}{c}\text { Flame } \\
\text { seedless }\end{array}$ & $\begin{array}{c}\text { Early } \\
\text { sweet } \\
\text { seedless }\end{array}$ & $\begin{array}{c}\text { Sugraonese } \\
\text { edless }\end{array}$ & & $\begin{array}{c}\text { Flame } \\
\text { seedless }\end{array}$ & $\begin{array}{c}\text { Early } \\
\text { sweet } \\
\text { seedless }\end{array}$ & $\begin{array}{l}\text { Sugraonese } \\
\text { edless }\end{array}$ & \\
\hline Palmito & 0.50 & 0.47 & 0.55 & 0.51 & 0.53 & 0.47 & 0.56 & 0.52 \\
\hline Chlorpyrifos & 0.48 & 0.46 & 0.50 & 0.48 & 0.50 & 0.46 & 0.53 & 0.50 \\
\hline Imidacloprid & 0.47 & 0.44 & 0.50 & 0.47 & 0.49 & 0.45 & 0.52 & 0.49 \\
\hline Nun insecticides & 0.89 & 0.87 & 1.10 & 0.95 & 0.93 & 0.90 & 1.13 & 0.99 \\
\hline Mean & 0.59 & 0.56 & 0.66 & & 0.61 & 0.57 & 0.69 & \\
\hline \multicolumn{9}{|l|}{ L.S.D. at 0.05} \\
\hline Insecticides (A) & & 0.07 & & & & 0.05 & & \\
\hline Grape varieties (B) & & 0.05 & & & & 0.03 & & \\
\hline $\mathrm{A} \times \mathrm{B}$ & & NS & & & & 0.06 & & \\
\hline
\end{tabular}

\subsubsection{Titratable acidity $\%$}

Results obtained in Table (6) pointed out that Titratable acidity $\%$ was significantly affected by spraying with different insecticides in the $1^{\text {st }}$ and $2^{\text {nd }}$ seasons. Imidacloprid recorded lowest Titratable acidity $\%(0.47$ and 0.49$)$ in the $1^{\text {st }}$ season and $2^{\text {nd }}$ season, respectively, compared with untreated vines $(0.95$ and 0.99). Meanwhile, Palmito compound was recorded the highest Titratable acidity \% (0.51 and 0.52$)$ in the $1^{\text {st }}$ and $2^{\text {nd }}$ seasons, respectively.
Data arranged in Table (6) showed that the grape varieties differed significantly in Titratable acidity\%. The highest Titratable acidity\% (0.66 and 0.69) was observed in Sugraone seedless during the first and second season, respectively. Whereas the lowest Titratable acidity\% (0.56 and 0.57) was observed in Early sweet seedless in both seasons, respectively. These results agreed with those of Karibasappa and Adsule, 2008 \&Muhammed et al., (2018) who reported that, lowest acidity value in grapes varieties were because of subtropical climatic conditions. As 
high temperature during berry development, maturation and ripening increases the malic acid consumption and lower the acid accumulation which ultimately decreases the acidity level in fruit at maturity.

The interaction between grape varieties and different insecticides showed the significant differences in the second season.

\subsubsection{Berry diameter $(\mathrm{mm})$}

Data in Table (7) showed that the Berry diameter was significantly affected by spraying with different insecticides in the $1^{\text {st }}$ and $2^{\text {nd }}$ seasons. Imidacloprid recorded highest Berry diameter mm (19.56 and 19.22) in the $1^{\text {st }}$ season and $2^{\text {nd }}$ season, respectively, compared with untreated vines (16.22 and 16.44). Meanwhile, Palmito was recorded the lowest Berry diameter $\mathrm{mm}(18.56$ and 18.22$)$ in the $1^{\text {st }}$ and $2^{\text {nd }}$ seasons, respectively.

Table 7. Effect of grape varieties and different application insecticides on the Berry diameter $(\mathrm{mm})$ at harvest in the $1^{\text {st }}$ and $2^{\text {nd }}$ seasons, 2018/2019 and 2019/2020.

\begin{tabular}{|c|c|c|c|c|c|c|c|c|}
\hline \multirow[t]{2}{*}{ Insecticides } & \multicolumn{3}{|c|}{ Berry diameter (mm) (2018/2019) } & \multirow[t]{2}{*}{ Mean } & \multicolumn{3}{|c|}{ Berry diameter (mm) (2019/2020) } & \multirow[t]{2}{*}{ Mean } \\
\hline & $\begin{array}{c}\text { Flame } \\
\text { seedless }\end{array}$ & $\begin{array}{c}\text { Early } \\
\text { sweet } \\
\text { seedless }\end{array}$ & $\begin{array}{c}\text { Sugraonese } \\
\text { edless }\end{array}$ & & $\begin{array}{c}\text { Flame } \\
\text { seedless }\end{array}$ & $\begin{array}{c}\text { Early } \\
\text { sweet } \\
\text { seedless }\end{array}$ & $\begin{array}{c}\text { Sugraonese } \\
\text { edless }\end{array}$ & \\
\hline Palmito & 17.00 & 20.00 & 18.67 & 18.56 & 16.67 & 19.67 & 18.33 & 18.22 \\
\hline Imidacloprid & 17.67 & 21.00 & 20.00 & 19.56 & 17.33 & 20.67 & 19.67 & 19.22 \\
\hline Nun insecticides & 15.33 & 17.00 & 16.33 & 16.22 & 15.00 & 17.67 & 16.67 & 16.44 \\
\hline Mean & 16.92 & 19.58 & 18.75 & & 16.58 & 19.50 & 18.58 & \\
\hline \multicolumn{9}{|l|}{ L.S.D. at 0.05} \\
\hline Insecticides (A) & & 1.75 & & & & 1.30 & & \\
\hline Grape varieties (B) & & 0.96 & & & & 0.70 & & \\
\hline
\end{tabular}

Data illustrated in Table (7) recorded that the grape varieties differed significantly in Berry diameter. The highest Berry diameter (19.58 and 19.50) was observed in Early sweet seedless during the first and second season, respectively. Whereas the lowest Berry diameter (16.92 and 16.58) was observed in Flame seedless in both seasons, respectively. These results agreed with Bashandy et al. (2020) found that, there were significant differences between the studded cultivars in quality parameters. Concerning, the interaction between grape varieties and different insecticides showed the insignificant differences in both seasons.
On the light of the previous results, it could be recommending that Imidacloprid insecticide was better than chlorpyrifos in control of grape mealybug. Palmito compound give good control of grape mealybug and should use as alternative candidate, so it should be considered in integrated pest management (IPM) programs of control programme of grape mealy bug.

\section{References}

A.O.A.C. (1985) 'Association of Official Analytical Chemists' Official Methods of Analysis'. 14 ${ }^{\text {th }}$ Edition, AOAC, Arlington.

Anonymous (2001) 'Professional recommendation in agriculture pests control' Ministry of Agriculture \& Land Reclamation, Arab Republic of Egypt.

\section{Conclusion}


Bashandy, T., Kamel, S. and Ferweez, H. (2020) 'Evaluation of Yield, Fruit Quality and Molecular Diversity for Three Grape Cultivars under New Valley Conditions'. J. of Agricultural Chemistry and Biotechnology, Mansoura Univ., 11 (7): 229-233.

Charles, J. G. (1982) 'Economic damage and preliminary economic thresholds for mealybugs (Pseudococcus longispinus T-T.) in Auckland vineyards'. $N Z J$. Agric Res., 25: 415 - 420.

Chowański, S., Kudlewska, M., Marciniak, P. and Rosinski, G. (2014) 'Synthetic Insecticides - is There an Alternative?'. Polish Journal of Environmental Studies 23(20): 291-302.

Daane K. M., Bentley, W. J., Smith, R. J., Haviland, D. R. Weber, E. and Gispert, C. (2011) 'Vine mealybug' In: Bettiga L, Bentley WJ (eds) University of California grape pest management manual. University of California Press, Oakland, 125 - 135 pp.

Daane K. M., Almeida, R. P. P., Bell, V. A., Walker, J. T. S., Botton, M., Fallahzadeh, M., Mani, J. L., Miano, R., forza, S.,Walton, V. M. and Zaviezo, T. (2012) 'Biology and management of mealybugs in vineyards' In: Bostanian, N.J., Vincent, C., Isaacs, R. (Eds.), Arthropod Management in Vineyards. Springer, New York, pp. 271-307.

Daane, K. M., Bentley, W. J., Walton, V. M., Malakar-Kuenen, R., Millar, J. G. and Ingels, C. A. (2006) 'New controls investigated for vine mealybug' Calif Agric., 60:31-38.

Doutt, R. L. and Hagen, K. S. (1950) 'Biological control measures applied against Pseudococcus maritimus on pears'. J. Econ. Entomol, 43: 94 - 96.
Dubois, M., Gilles, K., Hamilton, J., Rebers P. and Smith, F. (1956) 'Colorimetric method for determination of sugars and related substances' Analytical Chemistry, 28(3): 350 - 356.

El-Salhy, A. M., Ebtsam, M. F., Eman, A. A.and Mona, M. D. (2019) 'Effect of GA3 and some plant extracts spraying on fruiting of Early Sweet Seedless grapevines' SVU. International Journal of Agricultural Sciences, 1(2): 54- 63.

Foldi, I., Kozar, F. (2006) 'Now species of Cataenococcus and Puto from Brazil and Venezuela, with data on other species (Hemiptera: Coccidea)' Nouv. Entomol. 22: 305-312.

Grasswitz, T. R. and Burts, E. C. (1995) 'Effect of native natural enemies on the population dynamics of the grape mealybug, Pseudococcus maritimus (Hom.: Pseudococcidae), in apple and pear orchards' Entomophaga 40: 105 117.

Hardy, N. B., Gullan, P. J. and Hodgson, C. J. (2008) 'A classification of mealybugs (Hemiptera: Pseudococcidae) based on integrated molecular and morphological data'. Syst Entomol., 33: 51-71.

Henderson, C. F. and Tilton, E. W. (1955) 'Tests with acaricides against the brown wheat mite' Journal of Economic Entomology, 48: 157-161.

Hsia, D. Y. Y., Inouye, T. and Wong, P. (1965) 'Altered metabolism of leucocytes in Down's syndrome' Clin. Res. 12:216.

Karibasappa, G. S. and Adsule, P. G. (2008) 'Evaluation of wine grape genotypes by national research centre for grapes at their farm at Pune, Maharashtra, India' In International Symposium on Grape Production and Processing 785: $497-$ 504. 
Kent, M. D., Glenn Y. Y., Vaughn, M. W., Brian N. H., Monica, L. C., Walter J. B. and Jocelyn G. M. (2020) 'Development of a Mating Disruption Program for a Mealybug, Planococcus ficus, in Vineyards' Insects J. 11(9): 635-655.

Lo, P. L. and Walker, J. T. S. (2010) 'Good results from a soil-applied insecticide against mealybugs' $N, Z$ Winegrower 14 : $125-127$.

Madsen, H. F. and McNelly, L. B. (1960) 'Control of the grape mealybug on apricots' J. Econ. Entomol., 53: 354 357.

Maurya, P. K. and Malik, D. S. (2016) 'Bioaccumulation of Xenobiotics Compound of Pesticides in Riverine System and Its Control Technique' $A$ Critical Review Journal of Industrial Pollution Control, 32: 580-594.

McKenzie, H. L. (1967) 'Mealybugs of California with taxonomy, biology and control of North American species' University of California Press, Berkeley. Morandi Filho J. W., Grützmacher, A. D., Botton. M. and Bertin. M. (2008) 'Biologia e tabela de vida de fertilidade de Planococcus citri em diferentes estruturas vegetativas de cultivares de videira' Pesq. Agropec. Bras. 43(8):941947.

Muhammad, A. F., Naveeda, A., Ayesha, M. 1., Muhammad, T. and Muhammad, S. I. (2018) 'Performance of seven early maturing varieties of grapes (vitis vinifera) under agro- climatic conditions of pothwar, pakistan'. Pak. J. Biotechnol. 15 (4): 921-926. www.pjbt.org

Özgökçe, M. S., Esra, K. and Kara, H. (2018) 'Life table and some biological features of Planococcus citri, Risso (Hemiptera: Pseudococcidae) on 41-B grapevine variety (Vitis vinifera L.)'. YYÜ TAR BIL
DERG (YYU J AGR SCI) 28(özel sayı): 247-256

Srinivas, T., Prasad, K. S., Shekhar, M. A. and Manjunath, D. (2007) 'Evaluation on neem-based formulations vis-a-vis Dichlorvos against Maconellicoccus hirsutus'. Uttar Pradesh Journal of Zoology, 27(1): 13-20.

Sunitha, N. D., Jagginavar, S. B. and Biradar, A. P. (2009) 'Bioefficacy botanicals and newer insecticides against grape vine mealybug, Maconellicoccus hirsutus (Green)'. Karnataka J. Agric. Sci., 22(3): $710-711$.

Williams, D. J. and Watson, G. W. (1988) 'The Scale Insects of the Tropical South Pacific Region. Part 2. The Mealybugs (Pseudococcidae)'. CAB International, Wallingford, $257 \mathrm{pp}$.

Williams, D. J., and Granar de Willink M. C. (1992) 'Mealybugs of Central and South America'. $\quad C A B$. International, Wallingford. 